\title{
ERP Adoption and Organizational Efficiency- Balance Score Card Approach among Manufacturing SMEs in Kenya
}

\author{
Stephen Muchina \\ Deparment of Business and Enterprenuership, Karatina University, Kenya \\ E-mail: muchinavs@gmail.com
}

Received: Sept. 8, 2017 Accepted: Oct. 12, 2017 Published: Feb. 26, 2018

doi:10.5296/bmh.v6i1.11826 URL: http://dx.doi.org/10.5296/bmh.v6i1.11826

\begin{abstract}
ERP are comprehensive, fully integrated software packages that provide automated support for most of the standard business processes within organizations. The uptake of ERP in the industry has been impressive but not for SMEs. The SME market in the eyes of ERP developers has been un-lucrative because it is fairly fragmented and rudimental. This means that solutions adopted for one enterprise are not easily replicated on others in the same category. The paper determined the level and extent of ERP adoption in SMEs based in manufacturing sector and the accruing benefits towards organization efficiency as measured using a balance score card (BSC) approach. This study purposively sampled firms under Kenya Industrial Estate cells. In each cell, four firms were selected the inclusion criteria being a manufacturing enterprise and adoption of ERP. Using the BSC five factor model, the effect of ERP adoption was measured. Cross sectional data was collected on a five point Likert scale. This data set gave rise to categorical data. The relationship between ERP adoption and organizational performance was model using a Chi-Square test of independence. The study finds that there at the beginning phase except for customer satisfaction, financial strength, employee perspectives, internal business processes and innovation are independent of ERP adoption. At the consolidation and maturity phases the financial strength, employee perspectives, internal business processes and innovation become dependent on ERP adoption meaning the strength of these factors is determined by the ERP
\end{abstract}

Keywords: Enterprise Resource Planning adoption, SMEs, Organizational Efficiency and Balance Score Card 


\section{Introduction}

It is the desire of every entity to process data as meticulously as possible to give the attendant information much quality as possible. Organizations therefore have been increasingly investing towards purchasing software packages throughout the 1990s. One such infrastructure is Enterprise Resource Planning (ERP) systems. ERP are comprehensive, fully integrated software packages that provide automated support for most of the standard business processes within organizations. In the words of (Deloitte, 1999) ERP system are a packaged business solution that are designed to automate and integrate business processes, share common data and practices across the enterprise and provide access to information in a real time environment.

The uptake of ERP in the industry has been impressive. AMI-partners (2010) following a global survey on ERP usage found that ERP usage is well established in the developed regions of Asia Pacific (50\%), Western Europe (49\%), and North America (41\%). They also found that emerging markets are gaining momentum in ERP investments as shown by usage in Eastern Europe, the Middle East, and Africa (35\%) and Latin America (29\%). These statistics confirm that ERP have revolutionized business processes and are not a reserve of any region in the world.

The market penetration of ERP systems varies considerably from industry to industry. A report by Computer Economics Inc. stated that $76 \%$ of manufacturers, $35 \%$ of insurance and health care companies, and $24 \%$ of Federal Government agencies already have an ERP system or are in the process of installing one (Stedman, 1999).

The global market for ERP software, which was $\$ 16.6$ billion in 1998, was expected to have a compound annual growth rate of 32\%, reaching more than $\$ 66$ billion in sales by 2003 (Carlino, 1999b) and is estimated to have had 300 billion dollars spent over the last decade (Carlino, 1999a). It is important to note that trend is changing because firms' significant investments in ERP and the accompanying hardware is one off. The firm is left to foot the bill of maintenance cost which in comparison to initial costs represents lesser fortune to ERP developers.

While ERP developers have promised and delivered solutions to manage business and coordination complexities effectively according to (Buonanno et al., 2005), a shift in focus is required to the forgotten market segment- the SMEs.

The SME market in the eyes of ERP developers has been un-lucrative because it is fairly fragmented and rudimental. This means that solutions adopted for one enterprise are not easily replicated on others in the same category. On the other hand, SMEs management practices and business process may not necessarily be complex enough to be complemented by an ERP system. It is also felt that SMEs may not adequately support financially the ERP development process.

This said SMEs have however within their limitations adopted ERP systems in bid to continue playing the key role they play in economies. Upadhyay \& Dan (2010), report that $60-70 \%$ of SME annual infrastructure budget in India goes to financing ERP and related IT 
infrastructure. Similar observations are made by (Mullins et al., 2011) who found out that about 58\% of SMEs surveyed in Greece had adopted some form of ERP system. Whether SMEs are adopting ERP is not in question. What is debatable is whether there are any attendant benefits to this adoption especially in emerging markets like Kenya where this adoption can be a painstaking process.

\section{Literature Review}

\subsection{ERP Adoption in Sub-Sahara Africa}

Though there is paucity of data in relation to ERP adoption in Africa, adoption in Africa has largely been driven by technology transfer especially courtesy of the mother enterprise particularly for multinational enterprises, desire to bench mark industries best practices and the drive to comply to underlying regulation and industrial technology changes. For example, in commercial banking enterprise has seen the service requirements for interbank money transfer change from Society for Worldwide Interbank Financial Telecommunication (SWIFT) to Electronic Fund Transfer (EFT) to Real Time Gross Settlement (RTGS). Such circumstances could cause even the most conservative companies to change.

Another driver for ERP adoption in this environment according to (Huang et al., 2004) is economic growth which is making enterprises in this market to become obvious targets of ERP vendors. The governments of these regions have also made significant infrastructural investments in ICT especially in Kenya, Ghana, South Africa, and Nigeria which includes development of undersea cables connecting the continent to other parts of the world thus linking inland businesses to the world.

The challenges though have been massive. Huang \& Palvia (2001) fault this transfer of information systems like ERP since it is often marred by problems of mismatch with local, cultural, economic and regulatory requirements. There are concerns too that ERP implementation is likely to be more problematic in developing countries. Indeed Otieno (2008) cites the poor installation of the ERP system as one of the reasons which contributed to insolvency of Uchumi supermarket; a premier chain business in Kenya during 2006.

According to Jacobson et al. (2007) some major trends from observed in the global ERP market indicate that ERP vendors that traditionally offered a single, internally developed product line now go to market with a broad portfolio of products targeted to specific industry and departmental buyers. The report also note that Oracle and SAP continue to dominate the market among very large global companies. In the increasingly important SMB segment, though, they face formidable competition from Infor, Sage Group, Microsoft, Lawson, and Epicor.

On the SMEs front, ERP acquisition has not been a priority. The loftiness of the main ERP solutions is the main undoing towards such adoption. Developers however, are working closely with SMEs to produce low cost ERP solutions, these solutions have been made to provide full-fledged web based ERP systems, Electronic point of sale systems (EPOs), as well as payroll and Human resource solutions. (Jacobson et al., Ibid) 


\subsection{Benefits of ERP}

While each organization has unique information needs and processes, ERP has the capacity to accrue similar benefits across board irrespective of size, nature or sector where the firm is based. Davenport et al. (2002) have highlighted ten key benefits that are expected with successful ERP implementation among them being improved management decision making, improved financial management and improved customer service and retention. Notable though is that this list of benefits does not provide any category and neither does it show which were most relevant and applicable to the organization studied a gap this study wishes to address.

Consequently, other studies have tried to classify benefits for the purposes of identification. Delloite (1998) have identified two types of benefits; tangible and intangible. Tangible benefits include inventory and personnel reduction, productivity improvements and order management improvement among others. On the other hand, intangible benefits were seen as information visibility and new improved processes.

Though these benefits generally point to the well-being of the firm arising from ERP implementation, empirical results have shown some interesting findings sometimes confounding. Sircar et al. (2000) discovered that IT investments have a strong positive relationship with sales, assets and equity, but not with net income. They also indicated that spending on IT staff and staff training is positively correlated with firm performance, even more so than computer capital.

Further analysis suggests that many of the derived benefits from information technology systems are not accounted for as a result of the methods used to assess IT's impact on the organization (Cline \& Guynes, 2001; Thatcher \& Oliver, 2001). Finance managers are becoming aware of the effect of intangible assets of the firms earnings and futures cash flows (King \& Henry, 1999) provide evidence for the argument that intangible evaluation should be included in many project valuation settings.

In the study by Delloite (ibid), the most significant tangible benefits- inventory reduction was realised by $32 \%$ of firms surveyed while on the intangible front, information visibility was realised by $55 \%$ of the respondents. This shows that while there is a tendency by finance managers to measure tangible benefits because of their quantitative nature, a complementary measurement for intangible benefits is required. This paper strives to do exactly that hence the BSC.

\subsection{The Balance Score Card}

The BSC model was developed and promoted by Kaplan \& Norton (1992; 1993; 1996). Accordingly, they attempt to provide answers to four questions they premise are a concern of most enterprises. The being; how do customers perceives us? What must we excel at? Is it possible to continuously improve and create value? And how do relate to shareholders? These four questions have in return provided four variables which can be used to measure organisation efficiency from a BSC approach thus customer satisfaction; innovation/growth and learning perspective; internal business processes and financial perspective 
BSC has received much acclaim in industry. According to Chand et al. (2005) in 2001, the BSC had been adopted by 57 per cent of organisations in the UK, and by 46 per cent of organisations in the US (Neely et al., 2004). There is no evidence of BSC usage of firms resident in Africa and Kenya is no exception.

Garengo et al. (2005) acknowledge that BSC is one of the generic performance measurements systems which have been used by SMEs. Jamil \& Mohamed (2011) also agree that the multi-dimensional measures are particularly important and help to overcome the limitations of traditional performance measurement systems that only focus on the financial dimension especially the limitation of lack of financial data. These facts have not been lost on this paper hence the choice of the BSC model.

\subsection{A conceptual Framework}

Improved performance arising out of ERP adoption has been found to depend on several varied factors. Davenport et al. (2002) puts a strong case of performance depending on capacity of ERP to Integrate, Optimize, and Informate. Integrate is where a company is able to integrate their data and processes internally and externally with customers and suppliers. If optimization is attained it leads to the standardization of business processes incorporating best business practice while Informate is the ability to provide context rich information to support effective decision making.

Delloite (1999) have regarded performance as time bound dependent on the phase of ERP implementation which the firm is currently pursuing. The initial phase is known as the first wave whose benefits include being able to build a live ERP system. Majority of the benefits according to Delloite are deemed to occur in the second wave since processes will stabilise, giving rise to synthesis and synergy. The third wave will concretize the preceding benefits. These perspectives have been reinforced by Nolan \& Norton (2000) where they grouped implementations into three levels of maturity. Beginning phase-implemented ERP in the past 12 months, Consolidating phase - implemented ERP between 1 and 3 years, and Mature phase-implemented ERP for more than 3 years. This paper considered the progression of the benefits within these stages as control variable.

Organisational performance will be measured using the Balance Score Card five factor matrix (Kaplan \& Norton, 1992; 1996). ERP implementation is viewed by firms, users and vendors alike as a strategic niche capable of providing positive responses to all these questions. The conceptual framework of this paper therefore considers an integrated performance measurement as illustrated in figure 1 below. Based on this framework the following research hypotheses which were tested in respect to experience in SME subsector especially in manufacturing.

$\mathbf{H}_{1}$ : Financial performance is independent of ERP adoption phase.

$\mathbf{H}_{2}$ : Quality of customer or client service is independent of ERP adoption phase.

$\mathbf{H}_{3}$ : Human perspectives are independent of ERP adoption phase.

$\mathbf{H}_{4}$ : Internal Business Processes are independent of ERP adoption phase. 
$\mathbf{H}_{5}$ : Innovation, Growth and Learning are independent of ERP adoption phase.

The modalities of testing these hypotheses are discussed in the methodology section.

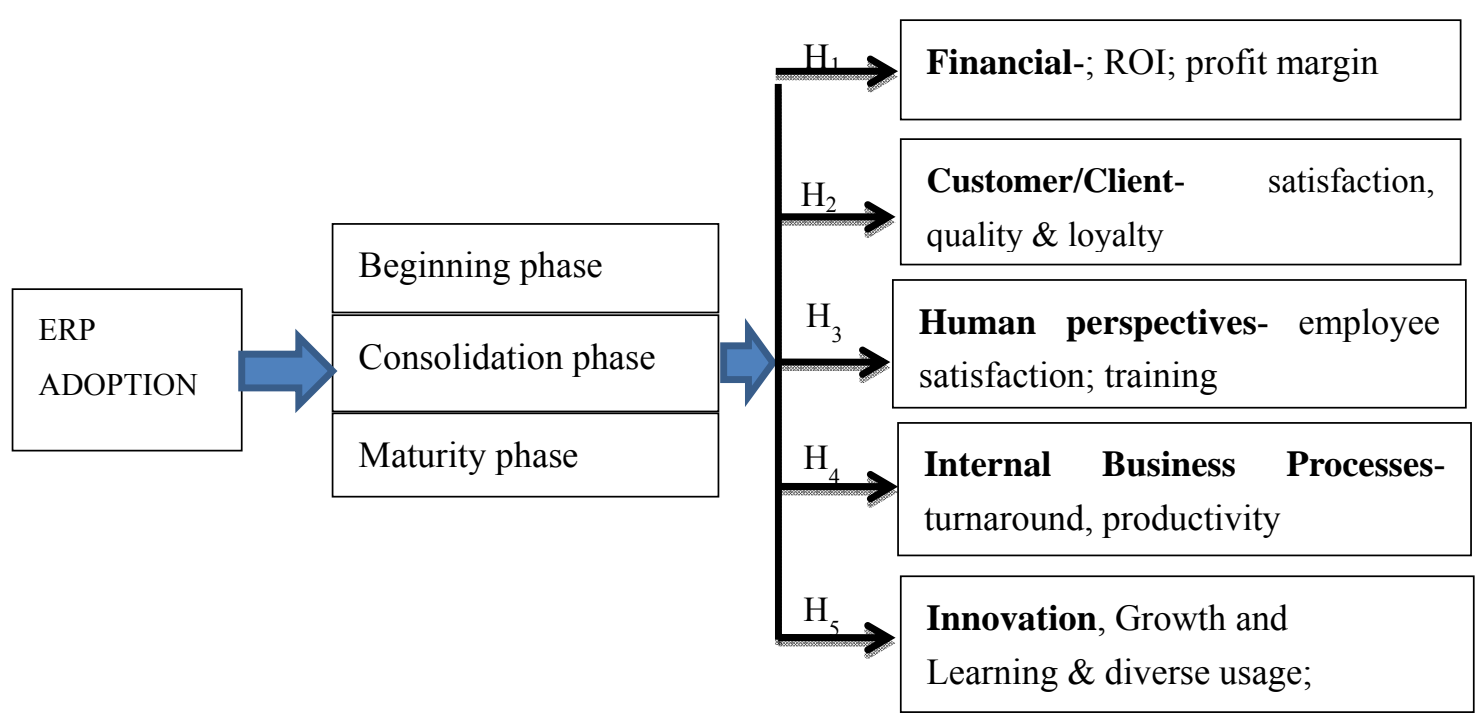

Figure 1. Conceptual framework

\subsection{Value of the Paper}

Effective participation of SMEs in commerce and the value chain at large is dependent on how adoptable they are to changing business environment. These changes include but are not limited to technological changes. This study therefore goes a long way to measure this adoptability and its attendant benefits.

The adoption and implementation of ERP like any other strategic move requires a well thought out plan. The difficulty is felt more in a SME environment because they are less endowed in terms of financial and human resource capacity. ERP systems are also built with due regard to large corporations who are capable of funding research and experiment costs involved and may not necessarily serve the peculiarity of SMEs. The replication or toning down of such ERP systems may occasion distortion and bugs in the system and such initial errors may kill the noble intention of technology simplification and transfer.

Albeit these handicaps SMEs have realized the need to make such drastic moves and adopt ERP in the hope that attendant and promised benefits accrue. Authors, developers and merchandiser's alike promise a wide range of benefits as discussed elsewhere in this paper. Key among them is organizational efficiency which is actually improved performance. While performance can be objectively measured from the a financial perspective, SMEs reporting requirements do not leave much information in public domain and given the sensitivity of such information, practically it may never be forthcoming for empirical use hence the decision to therefore used the Balance Score Card (BSC) approach to measure that performance. The study still finds insufficient evidence both in literature and empirically to 
support the evidence of ERP usage and SME performance in Kenya

\section{Methodology}

Studying SMEs is cannot be divorced from entrepreneurship theory and in light of this; the study makes particular reference to cluster theory for anchoring its methodology. Cluster theory premises that enterprises will agglomerate geographically motivated by availability of trading sectors, related sectors and supporting institutions (Porter, 1990, 1998, 2001; Bergmann \& Feser, 1999). A cluster has therefore been defined by Rocha (2002) as a geographically proximate group of firms and associated institutions in related industries linked by economic and social interdependencies. The Kenya Industrial Estate (KIE) is one of such clusters that exist in Kenya. KIE is conceived as an industrial home for SMEs. Its primary role is to facilitate growth of manufacturing at SME level by not just by providing funds but also premises for leasing. KIE is therefore typically a cluster of factories in which ever towns they are located. Currently, there are thirty two (32) industrial estates spread across Kenya (www.kie.co.ke).

This study purposively sampled firms under KIE cells. In each cell, four firms were selected the inclusion criteria being a manufacturing enterprise and adoption of ERP. The resultant sample size was 128. The manufacturing characteristics of enterprises in Kenya are fairly homogenous irrespective of location thus another justification for the sampling technique used.

Using the BSC five factor model, the effect of ERP adoption was measured. Cross sectional data was collected on a five point Likert scale. This data set gave rise to categorical data. The relationship between ERP adoption and organizational performance was model using a Chi Square test to independence.

\section{Results and Discussions}

Establishment characteristics results are presented in Table 1, commencing with data pointing out to the classification of SMEs. The study found that $70 \%$ of the enterprises surveyed had at least 100 employees. Annual turnover earned by the firms ranged from below shillings 1 million to above 15 million with a cumulative $84 \%$ of the firms reporting at least 1 million in earnings to 15 million. Blackburn \& Smallbone (2008) acknowledge the difficulty involved in classifying enterprises as small or medium given the lack of the universality in measures of employment and turnover. The situation is not made better by the lack of localized legislation on the SME categorization in Kenya. The sectors surveyed were found to be food processing, clothing and textile and steel and metal fabrication representing $24 \%, 15 \%$ and $17 \%$ respectively.

Varied ERP systems were found to be in use MS-ERP and Sage ACCPAC. The study is cognizant that the findings reflect a reserved or absent use of high market ERP software such as SAP, a finding that connotes cost constraints. Also $52 \%$ of the firms used custom made ERP solutions meaning that local software designers and manufacturers were taking up the challenge of producing affordable ERPs for SMEs use. These findings are also consistent with Kashorda (20015) who reported that SMEs in Kenya had slowly embraced ICT usage 


\section{Macrothink}

Business and Management Horizons

ISSN 2326-0297

2018, Vol. 6, No. 1

for their businesses access barriers in the form of costs notwithstanding. Further the study finds that $28 \%$ of the enterprises have had ERP introduced within the year meaning that they are still in the introductory phase. Another $60 \%$ are in the concrete phase while the remaining $12 \%$ are experiencing maturity in ERP usage.

ERP usage is defined as operational, tactical or strategic. Operational usage was predominantly seen in supply chain management and finance at $78 \%$ and $66 \%$ respectively. Tactical or strategic usage revolved around production scheduling and strategies planning with a small $4 \%$ reporting use in making capital budgets. Information needs of SMEs are to some extent rudimental when compared to large business organizations and this may impede on the effectiveness of use of information delivered by an ERP which introduces another view to the debate: that of optimality.

ERP adoption is never without challenges. This study found out that staff capacity to use ERP systems beleaguered the firms most and was experienced all of them. Other challenges in order of commonality were found to be cost of ERP, equipment and maintenance, systems failure and system security. Again as recognized in literature, these challenges may not be unique to SMEs but given that most of them are resource oriented, they may cause initial weariness on the finances of enterprises involved.

In order to test the hypotheses itemized earlier, the study applied a Chi Square test of independence. As stated in the conceptual framework, benefits arising out of ERP adoption were compartmentalized into phases of beginning, consolidation and maturity and presented in Table 2.

In respect to beginning phase, the hypothesis that ERP adoption is independent financial benefit derived by the firm was accepted since the $p$ value is 0.0001 for ROI and 0.0013 for profit margin hence insignificant. Similar results were observed in relation to human perspectives of employee satisfaction and training. The same findings are inferred on innovation benefits of learning and diverse usage. 
Table 1. Establishment characteristics

\begin{tabular}{|c|c|c|c|c|c|}
\hline Variable & $\mathrm{N}=128$ & Variable & $\mathrm{N}=128$ & Variable & $\mathrm{N}=128$ \\
\hline Number of Employees & & ERP System in Use & & Challenges & \\
\hline $1-50$ & $13 \%$ & MS-ERP & $12.3 \%$ & Cost of equipment & $88 \%$ \\
\hline $51-100$ & $17 \%$ & Sage ACCPAC & $10.5 \%$ & $\begin{array}{l}\text { Cost of } \\
\text { acquisition }\end{array}$ & $96 \%$ \\
\hline $101-150$ & $38 \%$ & Custom made & $52 \%$ & $\begin{array}{lll}\text { Cost of } & \text { ERP } \\
\text { maintenance } & \\
\end{array}$ & $78 \%$ \\
\hline $151-200$ & $24 \%$ & Others & $25.2 \%$ & Staff capacity & $100 \%$ \\
\hline$>201$ & $8 \%$ & $\begin{array}{l}\text { Duration Since ERP } \\
\text { Adoption }\end{array}$ & & Systems failure & $80 \%$ \\
\hline $\begin{array}{l}\text { Annual Turnover in KSh } \\
\text { millions }\end{array}$ & & $<1$ year & $28 \%$ & System security & $56 \%$ \\
\hline$<1$ million & $2 \%$ & $1-3$ years & $60 \%$ & & \\
\hline $1-5$ million & $40 \%$ & $>3$ years & $12 \%$ & & \\
\hline 5-10 million & $24 \%$ & $\begin{array}{l}\text { ERP Operational } \\
\text { Application }\end{array}$ & & & \\
\hline 10-15 million & $20 \%$ & Finance & $66 \%$ & & \\
\hline$>15$ million & $14 \%$ & SCM & $78 \%$ & & \\
\hline Manufacturing Sub Sector & & HRM & $24 \%$ & & \\
\hline Food processing & $24 \%$ & Marketing & $6 \%$ & & \\
\hline Clothing and textile & $15 \%$ & $\begin{array}{l}\text { ERP as Management } \\
\text { Information System }\end{array}$ & & & \\
\hline Steel and metal fabrication & $17 \%$ & Strategic Planning & $24 \%$ & & \\
\hline Others & $44 \%$ & Production scheduling & $52 \%$ & & \\
\hline & & Capital budgeting & $4 \%$ & & \\
\hline
\end{tabular}

On the other hand, the hypothesis that ERP adoption is independent of customer satisfaction was rejected since the $\mathrm{p}$ value in respect to customer loyalty was measured at 0.0124 , while that of service quality was found to be 0.0113 . In both cases, since alpha is 0.05 , the p values measured being greater are considered significant. Similar results have been inferred on internal business process benefits as operationalized in productivity and innovation benefits in the form of growth.

During the consolidation phase, all the hypotheses tested at this point in time are accepted. From Table 2, it can be observed that the $\mathrm{p}$ value for ROI is measured at 0.1313 and is found to be significant. Similar results are found in regards to profit margin, loyalty of customers, quality, employee satisfaction, training, turnaround, productivity, growth, diverse usage and learning. The study also found out that during the maturity phase in the adoption of ERP, the hypotheses tested were all rejected.

The results point out to the fact that during the beginning phase, no financial benefits accrued to the enterprise which adopted ERP. These firms were also slow in realizing benefits related to employees and innovation especially in relation to learning from ERP usage and diverseness. Immediate benefits were realized however in customer satisfaction since customers were noted to experience better service access, courtesy and timely delivery which led to customer retention and positive feedback. Growth in turnover was also experienced.

As the firms moved to other phases of ERP adoption, the benefits accrued more. Human 
perspectives improved in the form of employee satisfaction and training. Training needs become definite with time which makes training more focused towards building the pertinent skills. Growing employee satisfaction could be attributed to acceptable levels of change that has occurred in the earlier phases and general wellbeing that comes with improved work environment. These results are consistent with the findings of Sin Tan et al, (2010) found recommend that for SMEs to benefit effectively from ICT usage, they must be willing to send their employees for ICT training so as to hone their technical skills. Similar results are inferred in respect to internal business processes and innovation.

Table 2. Hypothesis testing

\begin{tabular}{|c|c|c|c|c|c|c|}
\hline \multirow{2}{*}{$\begin{array}{l}\text { ERP Implementation } \\
\text { Phase } \\
\text { Hypothesis } \\
\end{array}$} & \multicolumn{2}{|c|}{$\begin{array}{l}\text { Beginning phase } \\
\mathrm{n}=36\end{array}$} & \multicolumn{2}{|c|}{$\begin{array}{l}\text { Consolidation phase } \\
\mathrm{n}=76\end{array}$} & \multicolumn{2}{|c|}{$\begin{array}{l}\text { Maturity phase } \\
\mathrm{n}=16\end{array}$} \\
\hline & Chi square & $\mathrm{P}$ value & Chi square & P value & Chi square & $\mathrm{P}$ value \\
\hline \multicolumn{7}{|l|}{ H1 Financial: } \\
\hline ROI & $9.023(8)$ & 0.0001 & $16.589(8)$ & 0.1313 & $19.003(8)$ & 0.0531 \\
\hline Profit margin & $14.561(8)$ & 0.0013 & $17.101(8)$ & 0.1801 & $21.003(8)$ & 0.1013 \\
\hline \multicolumn{7}{|l|}{ H2 Customer satisfaction: } \\
\hline Loyalty & $26.981(15)$ & 0.0124 & $28.222(15)$ & 0.1192 & $26.991(15)$ & 0.1366 \\
\hline Quality & $31.432(20)$ & 0.0113 & $31.455(20)$ & 0.02134 & $36.311(20)$ & 0.0611 \\
\hline \multicolumn{7}{|l|}{ H3 Human perspectives } \\
\hline Employee satisfaction & $12.406(12)$ & 0.0000 & $22.499(12)$ & 0.0551 & $25.012(12)$ & 0.06533 \\
\hline Training & $17.349(12)$ & 0.0000 & $23.004(12)$ & 0.3101 & $24.233(12)$ & 0.2312 \\
\hline \multicolumn{7}{|l|}{$\begin{array}{ll}\text { H4 Internal business } \\
\text { processes }\end{array}$} \\
\hline Turnaround & $9.201(4)$ & 0.0002 & $11.342(4)$ & 0.0577 & $10.998(4)$ & 0.1031 \\
\hline Productivity & $25.147(15)$ & 0.0120 & $26.149(15)$ & 0.01201 & $25.198(15)$ & 0.2101 \\
\hline \multicolumn{7}{|l|}{ H5 Innovation } \\
\hline Growth (Turnover) & $10.448(4)$ & 0.0610 & $12.009(4)$ & 0.1331 & $14.112(4)$ & 0.1431 \\
\hline Learning & $8.341(4)$ & 0.0003 & $10.318(4)$ & 0.1435 & $10.882(4)$ & 0.1132 \\
\hline \multirow[t]{2}{*}{ Diverse usage } & $6.204(4)$ & 0.0000 & $12.118(4)$ & 0.1233 & $13.012(4)$ & 0.1030 \\
\hline & \multicolumn{6}{|c|}{$* \mathrm{P}$ values at $\alpha=0.05 ;$ degrees of freedo } \\
\hline
\end{tabular}

\section{Conclusions and Recommendation}

The study concludes that at the beginning phase except for customer satisfaction, financial strength, employee perspectives, internal business processes and innovation are independent of ERP adoption. At the consolidation and maturity phases the financial strength, employee perspectives, internal business processes and innovation become dependent on ERP adoption meaning the strength of these factors is determined by the ERP. Further, we conclude that SMEs in the manufacturing sector in Kenya have made significant progress in ERP adoption and have in return progressed towards higher levels of organizational efficiency despite the traditional challenges of ERP adoption.

Since the study has revealed that ERP adoption is beneficial to SMEs in relation to organizational performance, owing to the constraints of resources, the study recommends that SMEs plan to adopt ERP using in a phased manner because irrespective of when the investment is made, the benefits will accrue progressively. 
The study's findings are in respect to SMEs in the manufacturing sector meaning that findings may not be inferred on all sectors of economy. Further research may be carried out to determine the ERP adoption trends and experiences in other sectors across African states.

\section{References}

AMI-Partners. (2010). ERP Buyers' Guide for Growing Enterprises. [Online] Available: http://www.oracle.com/us/solutions/midsize/oa-external-june-news-488401.html

Bergman, E. M., \& Feser, E. J. (1999). Industry clusters: a methodology and framework for regional development policy in the United States. Boosting Innovation: The Cluster Approach, 243-268.

Blackburn, R. A., \& Smallbone, D. (2008). Researching small firms and entrepreneurship in the UK: Developments and distinctiveness. Entrepreneurship Theory and Practice, 32(2), 267-288. https://doi.org/10.1111/j.1540-6520.2007.00226.x

Buonanno, G., Faverio, P., Pigni, F., Ravarini, A., Sciuto, D., \& Tagliavini, M. (2005). Factors affecting ERP system adoption: A comparative analysis between SMEs and large companies. Journal of Enterprise Information Management, 18(4), 384-426. https://doi.org/10.1108/17410390510609572

Calogero, B. (2000). Who is to blame for ERP failure? Sun Server Magazine.

Carlino, J. (1999a). AMR Research Predicts ERP Market will Reach \$66.6 Billion by 2003. [Online] Available: www.amrresearch.com/press/files/99518. asp

Carlino, J. (1999b). AMR Research Unveils Report on Enterprise Application Spending and Penetration. [Online] Available: www.amrresearch.com/press/files/99823.asp

Chand, D., Hachey, G., Hunton, J., Owhoso, V., \& Vasudevan, S. (2005). A balanced scorecard based framework for assessing the strategic impacts of ERP systems. Computers in Industry, 56(6), 558-572. https://doi.org/10.1016/j.compind.2005.02.011

Cline, M. K., \& Guynes, C. S. (2001). A study of the impact of information technology investment on firm performance. Journal of Computer Information Systems, 41(3), 15-19.

Davenport, T. H., Harris, J. G., \& Cantrell, S. (2002). The return of enterprise solutions: The director's cut. Accenture Institute for Strategic Change Research Report, 14, 53.

Deloitte. (1999). "ERPs Second Wave," Deloitte Consulting.

Garengo, P., Biazzo, S., \& Bititci, U. S. (2005). Performance measurement systems in SMEs: A review for a research agenda. International Journal of Management Reviews, 7(1), 25-47. https://doi.org/10.1111/j.1468-2370.2005.00105.x

Jacobson, S., Shepherd, J., D’Aquila, M., \& Carter, K. (2007). The ERP market sizing report, 2006-2011. AMR Research, 29.

Jamil, C. M., \& Mohamed, R. (2011). Performance measurement system (PMS) in small medium enterprises (SMES): A practical modified framework. World Journal of Social 
Sciences, 1(3), 200-212.

Kaplan, R. S., \& Norton, D. P. (2007). Using the balanced scorecard as a strategic management system. Harvard Business Review, 85(7-8), 150-+.

Kaplan, R. S., \& Norton, D. P. (2001). Transforming the balanced scorecard from performance measurement to strategic management: Part II. Accounting Horizons, 15(2), 147-160. https://doi.org/10.2308/acch.2001.15.2.147

Kashorda, M. (2015). Measuring ICT Usage in the SME Sector ICT Indicators and Diffusion. [Online] Available: erepo.usiu.ac.ke

Kenya Industrial Estates. (2017). [Online] Available: http//:www.kie.co.ke

King, A. M., \& Henry, J. M. (1999). Valuing intangible assets through appraisals. Strategic Finance, 81(5), 32.

Neely, A., Kennerley, M., \& Martinez, V. (2004). Does the Balanced Scorecard Work. An Empirical Investigation, Centre for Business Performance, Cranfield School of Management, Cranfield..

Nolan and Norton Institute. (2000). SAP Benchmarking Report 2000, KPMG Melbourne.

Otieno, J. O. (2008). Enterprise Resource Planning (ERP) systems implementation challenges: A Kenyan case study. Business Information Systems (pp. 399-409). Berlin Heidelberg: Springer.

Porter, M. (1990). The Competitive Advantage of Nations. New York: The Free Press. https://doi.org/10.1007/978-1-349-11336-1

Porter, M. E. (1998). Clusters and the New Economics of Competition, 76(6), 77-90. Boston: Harvard Business Review.

Porter, M. E., \& Stern, S. (2001). Innovation: location matters. MIT Sloan Management Review, 42(4), 28.

Sircar, S., Turnbow, J. L., \& Bordoloi, B. (2000). A framework for assessing the relationship between information technology investments and firm performance. Journal of Management Information Systems, 16(4), 69-97. https://doi.org/10.1080/07421222.2000.11518266

Stedman, C. (1999). What's Next for ERP? Computerworld, 3, 48-49.

Sin Tan, K., Choy Chong, S., Lin, B., \& Cyril Eze, U. (2010). Internet-based ICT adoption among SMEs: Demographic versus benefits, barriers, and adoption intention. Journal of Enterprise Information Management, 27-55. https://doi.org/10.1108/17410391011008897

Thatcher, M. E., \& Oliver, J. R. (2001). The impact of technology investments on a firm's production efficiency, product quality, and productivity. Journal of Management Information Systems, 18(2), 17-45. https://doi.org/10.1080/07421222.2001.11045685 


\section{Copyright Disclaimer}

2018, Vol. 6, No. 1

Copyright for this article is retained by the author(s), with first publication rights granted to the journal.

This is an open-access article distributed under the terms and conditions of the Creative Commons Attribution license (http://creativecommons.org/licenses/by/3.0/). 